\title{
ANTIVIRAL ACTIVITY OF CASHEW NUTSHELL EXTRACT AGAINST Cowpea mild mottle virus ON SOYBEAN
}

\author{
Wuye Ria Andayanie ${ }^{1}$, Wahidin Nuriana ${ }^{1}$, \& Netty Ermawati ${ }^{2}$ \\ ${ }^{1}$ Department of Agrotechnology, Faculty of Agriculture, Universitas Merdeka Madiun, Indonesia \\ Jl. Serayu 79 Madiun 6311 \\ ${ }^{2}$ Politeknik Negeri Jember, Department of Agriculture and Production, Indonesia \\ Jl. Mastrip Jember \\ E-mail: wuye.andayanie@gmail.com
}

\begin{abstract}
Antiviral activity of cashew nutshell extract against Cowpea mild mottle virus on soybean. Cowpea mild mottle virus (CPMMV) is one of the important viruses infecting soybeans. The CPMMV disease management usually done by controlling the vector with insecticides that cause negative impact to the environment and non-target insects. Therefore, it is important to find safer alternative to control the disease such as the use of plant extracts. Cashew nutshells (CNS) are waste during cashew processing and contain several antimicrobial substances. This study aimed to evaluate the potential of CNS extracts to inhibit CPMMV infection. The experiment was designed with a randomized block design with 4 replications and each treatment unit consisted of 10 plants. The application method consisted of spraying the leaves before and after virus inoculation and mixing the sap with CNS extract. CNS extract concentrations tested were $0.75 ; 1.5 ; 3.0 ; 6.0 \%$. The result showed that CNS extract applications can decrease the disease incidence and increase the incubation period. However, plants treated with CNS extracts at concentration of $3.0 \%$ and $6.0 \%$ before virus inoculation and mixing CNS extracts at concentration of $1.5 ; 3.0$ and $6.0 \%$ with CPMMV sap showed that the virus titer was detected negative by ELISA using CPMMV antiserum. The results indicated that the CNS extract has potency as antivirus for CPMMV. All treatment combinations can suppress viral infections without phytotoxicity, except for CNS $6.0 \%$.
\end{abstract}

Key words: antiviral, cashew nutshell extract, Cowpea mild mottle virus (CPMMV), soybean

\section{INTRODUCTION}

The soybean (Glycine max L.) productivity of Indonesia is quite low and unable to meet domestic needs, so the government continues to import soybean about 2.5 million tons every year. Some of the factors causing the low productivity of soybeans are climate factors, planting area and attack of pests and diseases. The mild mottle disease caused by Cowpea mild mottle virus (CPMMV). The mosaic disease caused by Soybean mosaic virus (SMV) and stunt disease by Cucumber mosaic virus soybean strain (CMVs) are important viruses of soybeans in Indonesia. Symptoms of CPMMV infection can not be distinguished from mosaic symptoms caused by SMV. This disease can reduce soybean yields around $14-18 \%$ and difficult to control (Andayanie et al., 2011). This is because the disease is spread by vectors, such as whitefly (Bemisia tabaci Genn.) and transmitted through soybean seeds (Tavassoli et al., 2008). Young soybean plants are more susceptible to CPMMV than adult plants. The disease control strategies were carried out by using resistant varieties, even though the number of resistant varieties is insufficient for the needs of farmers (Saleh, 2007; Andayanie \& Adinurani, 2014; Andayanie et al., 2017). Today, the disease control strategy is using the chemical insecticide against the virus vectors, but it is considered to be ineffective and has a negative impact on the environment, humans, and biological resources (Andayanie et al., 2019).

Plant systemic resistance to viruses can be activated by applying inducing agents from plant extracts. Gunaeni et al. (2015) reported that the active compound in the extracts of the japanese glorybower (Clerodendrum japonicum Thunb.) and periwinkle (Catharanthus roseus L.) can increase resistance to Pepper leaf curl virus infection in red chili. In addition, chrysanthemum (Tanacetum vulgare L.) flower extract has antiviral activity against Cucumber mosaic virus and Potato Y virus in tomato plants (Petrov et al., 2016). Cashew nutshell (Anacardium occidentale L.) is a waste in the process of cashew seeding, has many antimicrobial activities such as antibacterial and antifungal (Garcia et al., 2018; Sudjaroen et al., 2018). This extract also has activity as an insecticidal, molluscicidal, and herbicidal (Towaha \& Achmadi, 2011; 
Andayanie \& Ermawaty, 2019; Andayanie et al., 2018). Cashew nutshell contains anacardic acid compound (76.93\%), cardols (12.75\%), cardanol (4.66\%), 2- methyl cardanol (3.81\%) (Andayanie et al., 2019). Anacardic acid (6-pentadecylsalicylic acid) is a derivative of salicylic acid substituted by a long alkyl chain (Aderiye et al., 2015). Salicylic acid triggers an induce the activity of Pathogenesis-Related (PR) proteins, such as peroxidase, chitinase, $\beta-1.3$ glucanase, and $\beta-1.4$ glucosidases, prevent the viral multiplication, spread, and localize the viral infection, although it needs a retention period for systemic resistance after induced by the extract (Murphy et al., 2001; Elbeshehy, 2017). Salicylic acid derivative compounds in cashew nutshell have not been reported for their antiviral effect on plant viruses. Therefore, this study aimed to evaluate the potential of CNS extracts to inhibit CPMMV infection in soybean plants.

\section{MATERIALS AND METHODS}

Research Site. The study was conducted from May to October 2018 in the Laboratory of Plant Disease, Faculty of Agriculture, Universitas Merdeka Madiun. Cashew nutshell was obtained from cashew producer in Pondok Village, Ngadirojo District, Wonogiri Regency.

Experimental Design. The experiment was arranged in a randomized block design (RBD) consisting of 14 levels of treatment: 12 experimental treatments, CPMMV infected plants as positive control and healthy plants as a negative control. Each treatment was repeated 4 times and each treatment unit consisted of 10 plants. The 12 types of experimental treatment consisted of cashew nutshell extract treatment before CPMMV inoculation, after CPMMV inoculation and mixing the extract with CPMMV sap, with the concentration of $0.75 ; 1.5 ; 3.0$ and $6.0 \%$.

Planting the Test Plants. The Willis soybean variety and Chenopodium amaranticolor, respectively 2 and 4 weeks after planting were used as test plants. The plants were planted in polybags containing a mixture of soil and manure at 2:1 ratio and maintained in a screen house.

Inoculum Multiplication. The source of inoculums were obtained from the Laboratory of Plant Disease, Faculty of Agriculture, Universitas Merdeka Madiun since June 2018. The inoculums were isolated from the CPMVV infected soybean in Ngawi. The inoculums then purified in C. amaranticolor using the single spot inoculation method and inoculated mechanically to the Willis soybean variety at 10 days after planting (DAP), the infected plants then nurse in the screen house. On the 21 days after inoculation (DAI), the infected plants showed specific symptom of infection such as mosaic with vein clearing, and chlorosis. The CPMMV isolate with specific antiserum CPMMV (DSMZ) was detected by positive reaction on DAS ELISA. The young soybean leaves that showed specific symptom of infection cultivated at 28-42 days after planting and stored at $4{ }^{\circ} \mathrm{C}$.

Extraction and Treatment of Cashew Nutshell. Cashew nutshells were dried to a moisture content of $15-20 \%$ and ground to produce a 400 Mesh powder. Cashew nutshell powder $(500 \mathrm{~g})$ was moistened with n-hexane and ethanol (3:1) for 4 hours to produce the mass. Percolation was done by moving the mass gradually into the percolator and adding hexane and ethanol (3:1) solvents, then incubated at room temperature for 24 hours. The extract evaporated at $45{ }^{\circ} \mathrm{C}$ with a low-pressure vacuum $(500-550 \mathrm{mmHg})$ to produce concentrated extracts.

Incubation Period and Symptoms. The incubation period was calculated from CPMMV inoculation until the initial symptoms appear on the plant.

Disease Incidence and Disease Severity. The disease incidence and disease severity were observed weekly for each plants starting from 21 days after CPMMV inoculation until 49 DAI.

Disease incidence. The disease incidence was calculated using following formula:

DI : disease incidence

$$
\mathrm{DI}=\frac{\mathrm{n}}{\mathrm{N}} \times 100 \%
$$

$\mathrm{n}$ : number of plants showing CPMMV infection symptoms

$\mathrm{N}$ : number of observed plant

Disease severity. The disease severity was calculated using following formula:

$$
\mathrm{DS}=\frac{\sum(\mathrm{n} \times \mathrm{v})}{\mathrm{N} \times \mathrm{V}} \times 100 \%
$$

DS : disease severity

$\mathrm{n}$ : number of infected leaves with specific score

$\mathrm{v}$ : disease severity score

$\mathrm{N}$ : number of observed leaves/plant

$\mathrm{V}$ : highest severity score 
The scores of disease severity were performed based on Arif \& Hassan (2002) with minor modifications based on symptom patterns as follows (Figure 1): $1=$ healthy plants, mild yellow blotches (mottles)

$2=$ mild yellow blotches, no wrinkle (10-30\%)

$3=$ clear yellow blotches, slightly mosaic (30-50\%)

$4=$ Severe mosaic symptom $(51-70 \%)$, leaf distortion, plant dwarf

$5=$ Severe mosaic symptom $(>70 \%)$, plant dwarf or dead

Disease Development and Inhibition. The total area under the disease development curve $($ AUDPC $=$ Area Under Disease Progress Curve) were calculated at 21, $28,35,42$, and 49 DAI based on the formula (Strange, 2003):

$$
\operatorname{AUDPC}=\sum_{\mathrm{i}=1}^{\mathrm{n}} \frac{\left\lfloor\mathrm{Y}_{1}+\mathrm{Y}_{\mathrm{I}+1}\right\rfloor}{2}\left(\mathrm{t}_{\mathrm{i}+1}-\mathrm{t}_{\mathrm{i}}\right)
$$

$\mathrm{Y}_{1}=$ data on $\mathrm{i}^{- \text {th }}$ observation

$\mathrm{Y}_{\mathrm{i}+1}=$ data on $\mathrm{i}^{\text {th }}+1$ observation

$\mathrm{t}_{\mathrm{i}+1} \quad=$ time at $\mathrm{i}^{\text {th }}$ observation

$\mathrm{t}_{\mathrm{i}} \quad=$ time at $\mathrm{i}^{\text {th }}+1$ observation

$\mathrm{n} \quad=$ total number of observation

The percentage of systemic disease inhibition (P) CPMMV on the soybean due to the cashew nutshell extract were calculated by:

$P=\left|\frac{A U D P C \text { of possitive control - AUDPC experiment }}{\text { AUDPC of possitive control }}\right| \times 100 \%$

The percentage of CPMMV local inhibition in the C. amaranticolor induced by the cashew nutshell extract treatment was calculated by:

$$
\mathrm{P}=\frac{\mathrm{a}-\mathrm{b}}{\mathrm{a}} \times 100 \%
$$

$\mathrm{a}=$ number of local spot on the tested plants without nutshell extract treatment

$b=$ number of local spot on the tested plants with nutshell extract treatment
Serological Detection of CPMMV. The CPMMV detection was carried out at 28 DAI by DAS ELISA method. This method used CPMMV antiserum with procedures according to the recommendations of the antiserum maker (DSMZ, Braunschweigh, Germany) CPMMV infected plants without extract treatment (positive control) and healthy plants (negative control) were used as a comparison. Each treatment used 10 plants and from each plant 4 leaf samples were taken. The virus titer or virus accumulation was quantified by ELISA Reader (Bio-Rad Model 550) at a wavelength of $405 \mathrm{~nm}$.

Data Analysis. The obtained data were analyzed by analysis of variance (ANOVA) and the effect of significantly different treatments was followed by Duncan's multiple range test at a significance level of $5 \%$. In order to obtain homogenous data, prior analizing, the data of disease incidence and disease severity was transformed using $\arcsin \sqrt{x+0.5}$.

\section{RESULTS AND DISCUSSION}

\section{Selection of Cashew Nutshell Extract} Concentration. Application of cashew nutshell extract with various concentrations showed different abilities in suppressing CPMMV infection. Observation of the disease incidence was started since the early symptoms appear on the plants treated by cashew nutshell extract at 21 DAI. On the positive control, the yellow blotch was first appeared at $17 \mathrm{DAI}$, then developed into a mild mosaic and very severe mosaic. Plants with the treatment of cashew nutshell extract at a concentration of $0.75 ; 1.5 \%$ before CPMMV inoculation and cashew nutshell extract treatment at a concentration of 0.75 ; $1.5 ; 3.0 \%$ after CPMMV inoculation showed clear yellow spots at $21 \mathrm{DAI}$, then developed into a light mosaic. This symptom appeared lighter compared to the positive controls. The results revealed that cashew nutshell extract was able to suppress the development of symptoms due to CPMMV. The positive controls had a shorter incubation period than the experimental plants
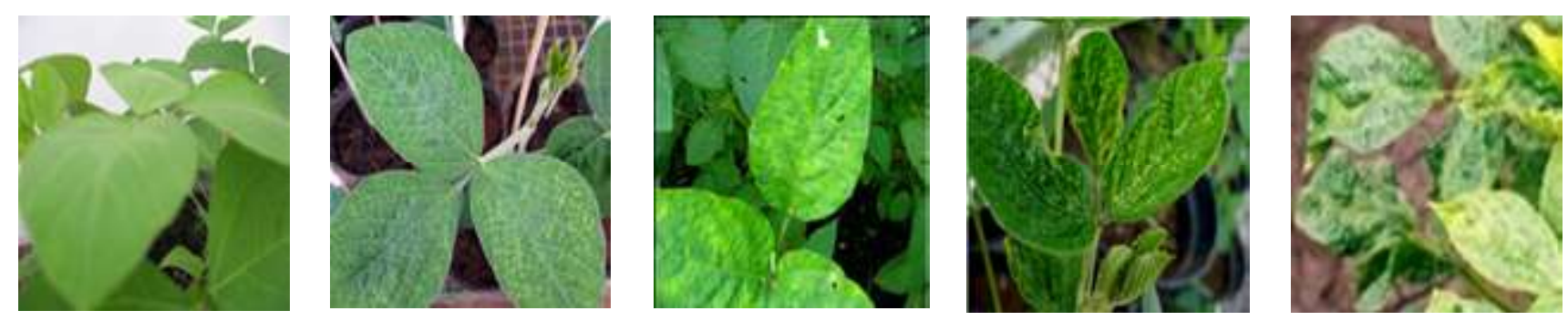

Figure 1. The score of disease severity. (A) score 1, (B) score 2, (C) score 3, (D) score 4, (E) score 5. 
with cashew nutshell extract. Plants treated with cashew nutshell extract at a concentration of 3.0; 6.0\% before inoculation with CPMMV and extract mixing treatment, each at a concentration of $1.5 ; 3.0 ; 6.0 \%$ with sap CPMMV and negative controls, revealed healthy leaves until the end of the observation time so that they did not have an incubation period. However, plants treated with cashew nutshell extract at a concentration of $6.0 \%$ before inoculation with CPMMV revealed mild phytotoxicity in the sprayed part of the extract. Cashew nutshell extract treatment was able to suppress the incidence of disease lower than positive control with a range of 0.11 to $5.92 \%$ at the end of the observation time (49 DAI) (Table 1).

The inoculation of $6.0 \%$ cashew nutshell extract in CPMMV sap to soybean plants did not show any development of disease incidence and severity at 21 DAI. Percentage of disease incidence since 28 DAI in cashew nutshell extract treatment at concentrations 3.00 and $6.00 \%$, compared to before CPMMV inoculation was not showing any significant symptoms improvement. The same result was also found in the treatments of mix cashew nutshell extract at concentrations of 3.00 and $6.00 \%$, respectively with CPMMV sap. The symptoms were consistent until 49 DAI. The same trends were also observed on the disease severity. Plant treated with mix of cashew nutshell extract with 3.00 and $6.00 \%$ concentration and CPMMV sap were not showed any escalation in disease severity percentage from 28 DAI till 49 DAI (Table 2). Cashew nutshell extract as a resistance inducer was not made the plant completely resistant, but it increases the plant resistance to CPMMV by inhibiting disease development. This is presumably due to the operation of the systemic defense genes, which inhibit the disease incidence in soybean plants. Plant defense genes required inducers and sufficient time to work effectively.

\section{The Inhibitory Activity of Cashew Nutshell}

Extract. Based on the preliminary research, the bioactive component in cashew nutshell extract consisted mainly of anacardic acid (6-pentadecylsalicylic acid) of $76.93 \%$ which is a derivative of salicylic acid (Andayanie et al., 2019). This bioactive compound was assumed to play a role in increasing resistance to CPMMV infection. According to Andayanie et al. (2011) and Gunaeni et al. (2015), disease incidence and intensity of soybean mosaic disease were related to the infection time, infected plant age, environment, and induction of plant resistance by various external treatments. The japanese glorybower leaf extract also has salicylic acid derivative compounds and plays a role for systemic acquired resistance (SAR) through salicylic-phenyl propanoid acid. The salicylic

Table 1. The effect of cashew nutshell extract application on disease incidence in soybean

\begin{tabular}{lllllll}
\hline \multirow{2}{*}{ Extract treatment } & \multirow{2}{*}{$\begin{array}{c}\text { Extract } \\
\text { concentration (\%) }\end{array}$} & \multicolumn{5}{c}{ Observation (DAI) (\%) } \\
\cline { 3 - 7 } & 0.75 & $1.74 \mathrm{~cd}$ & $2.05 \mathrm{c}$ & $2.13 \mathrm{~cd}$ & $2.38 \mathrm{c}$ & $2.38 \mathrm{c}$ \\
Before CPMMV inoculation & 1.50 & $1.38 \mathrm{~cd}$ & $1.45 \mathrm{c}$ & $1.85 \mathrm{~cd}$ & $2.10 \mathrm{c}$ & $2.10 \mathrm{c}$ \\
& 3.0 & $1.13 \mathrm{~cd}$ & $1.13 \mathrm{~cd}$ & $1.13 \mathrm{~cd}$ & $1.13 \mathrm{~cd}$ & $1.13 \mathrm{~cd}$ \\
& 6.0 & $0.41 \mathrm{~d}$ & $0.41 \mathrm{~d}$ & $0.41 \mathrm{~d}$ & $0.41 \mathrm{~d}$ & $0.41 \mathrm{~d}$ \\
After CPMMV inoculation & 0.75 & $2.75 \mathrm{c}$ & $3.12 \mathrm{~b}$ & $5.92 \mathrm{~b}$ & $5.92 \mathrm{ab}$ & $5.92 \mathrm{ab}$ \\
& 1.50 & $2.40 \mathrm{c}$ & $2.86 \mathrm{~b}$ & $4.86 \mathrm{bc}$ & $5.03 \mathrm{~b}$ & $5.03 \mathrm{~b}$ \\
& 3.0 & $2.15 \mathrm{c}$ & $2.40 \mathrm{bc}$ & $2.68 \mathrm{bc}$ & $2.72 \mathrm{c}$ & $2.72 \mathrm{c}$ \\
Mixed with & 6.0 & $1.29 \mathrm{~cd}$ & $1.32 \mathrm{c}$ & $1.75 \mathrm{~cd}$ & $1.87 \mathrm{c}$ & $1.87 \mathrm{c}$ \\
CPMMV sap & 0.75 & $1.21 \mathrm{~cd}$ & $1.82 \mathrm{c}$ & $2.01 \mathrm{~cd}$ & $2.30 \mathrm{c}$ & $2.30 \mathrm{c}$ \\
& 1.50 & $1.10 \mathrm{~cd}$ & $1.28 \mathrm{c}$ & $1.28 \mathrm{~cd}$ & $1.28 \mathrm{c}$ & $1.28 \mathrm{c}$ \\
Negative control & 3.0 & $0.38 \mathrm{~d}$ & $0.38 \mathrm{~d}$ & $0.38 \mathrm{~d}$ & $0.38 \mathrm{~d}$ & $0.38 \mathrm{~d}$ \\
Positive ccontrol & 6.0 & $0.15 \mathrm{~d}$ & $0.15 \mathrm{~d}$ & $0.15 \mathrm{~d}$ & $0.15 \mathrm{~d}$ & $0.15 \mathrm{~d}$ \\
CV (\%) & - & $0.11 \mathrm{~d}$ & $0.11 \mathrm{~d}$ & $0.11 \mathrm{~d}$ & $0.11 \mathrm{~d}$ & $0.11 \mathrm{~d}$ \\
\hline
\end{tabular}

DAI: days after inoculation; CV: coefficient of variation; the same letter at each column showed the no significance different based on Duncan multiple range test at significance level of 5\%. 
acid content in red chili pepper plants treated with japanese glorybower and periwinkle was higher than control on the plants infected by the curly virus. Salicylic acid triggers the formation of Pathogenesis-Related (PR) protein and prevents the multiplication, spread, and localization of viruses (Kristyaningrum et al., 2015; Gunaeni et al., 2015).

Inhibition Properties of Cashew Seed Extract Towards CPMMV. Currently, there were no reports about cashew nutshell extract in activating defense control genes in plants as a reaction to pathogenic infections. However, some applications of cashew nutshell extract as an inducer showed it capability to induce plant resistance to CPMMV in soybean. The application of cashew nutshell extract as an induction against CPMMV infection has a lower value of area under disease progress curve (AUDPC) than positive control or plants that were inoculated with CPMMV without any extract application. The higher the AUDPC value, the lower the inhibition percentage locally and systemically. The largest AUDPC value for cashew nut shell extract treatment after CPMMV inoculation was in concentration of $0.75 \%$, with AUDPC value of 115.78 indicating a local inhibition of 30.32 and a systemic of 18.18 (Table 3).
Local inhibition on indicator plants (C. amaranticolor) and systemic on host plants from cashew nutshell extract have an average value of 74.83 and $56.35 \%$, respectively. Extract treatment before inoculation of CPMMV at concentrations 3.0 and $6.0 \%$, after inoculation of CPMMV at concentrations of $6.0 \%$, and mix of cashew nutshell extract and CPMMV sap at concentrations $(1.5 ; 3.0 ; 6.0 \%)$ had the percentage of local and systemic inhibition above the average. This showed that the treatment was able to induce resistance against CPMMV in soybean. Besides that, the mix of cashew nutshell extract at $6.0 \%$ concentration and/ CPMMV sap had the lowest AUDPC value (5.25) and the highest percentage of local and systemic inhibition was 97.85 and $85.21 \%$, respectively. The AUDPC value was followed by the treatment of cashew nutshell extract at a concentration of $1.5 \%$ in CPMMV suction and cashew nutshell extract at concentrations ( 6.0 and 3.0\%) with prior inoculation of CPMMV respectively 32.29 ; $39.82 ; 50.44$.

Virus Detection by ELISA. The positive control treatment confirmed the absorbance value of ELISA (NAE) $>2$ times the NAE of the negative control. CNS extract treatment $(3.0$ and $6.0 \%$ ) before CPMMV inoculation and CNS extract mixture $(1.5 ; 3.0 ; 6.0 \%)$

Tabel 2. The effect of cashew nutshell extract application on disease severity in soybean

\begin{tabular}{lcccccc}
\hline \multirow{2}{*}{ Extract treatment } & \multirow{2}{*}{$\begin{array}{c}\text { Extract } \\
\text { concentration }(\%)\end{array}$} & \multicolumn{5}{c}{ Observation time (DAI) (\%) } \\
\cline { 3 - 7 } & & & 21 & 35 & 42 & 49 \\
\hline Before CPMMV inoculation & 0.75 & $2.68 \mathrm{bc}$ & $3.28 \mathrm{bcd}$ & $4.45 \mathrm{cde}$ & $4.45 \mathrm{bcd}$ & $4.45 \mathrm{bcd}$ \\
& 1.5 & $2.11 \mathrm{c}$ & $2.63 \mathrm{~cd}$ & $2.83 \mathrm{de}$ & $3.07 \mathrm{cde}$ & $3.07 \mathrm{cde}$ \\
& 3.0 & $1.14 \mathrm{~d}$ & $1.22 \mathrm{de}$ & $2.22 \mathrm{de}$ & $2.22 \mathrm{def}$ & $2.22 \mathrm{def}$ \\
& 6.0 & $1.08 \mathrm{~d}$ & $1.77 \mathrm{de}$ & $1.98 \mathrm{de}$ & $1.98 \mathrm{ef}$ & $1.98 \mathrm{ef}$ \\
After CPMMV inoculation & 0.75 & $3.25 \mathrm{~b}$ & $4.84 \mathrm{bc}$ & $7.52 \mathrm{bc}$ & $7.52 \mathrm{ab}$ & $7.52 \mathrm{ab}$ \\
& 1.5 & $2.77 \mathrm{~b}$ & $4.31 \mathrm{bc}$ & $5.01 \mathrm{bcd}$ & $5.06 \mathrm{abc}$ & $5.08 \mathrm{abc}$ \\
& 3.0 & $2.75 \mathrm{bc}$ & $3.16 \mathrm{bcd}$ & $4.45 \mathrm{cde}$ & $4.93 \mathrm{abc}$ & $4.95 \mathrm{abc}$ \\
Mixed with & 6.0 & $1.42 \mathrm{~cd}$ & $2.27 \mathrm{~cd}$ & $2.51 \mathrm{de}$ & $2.70 \mathrm{de}$ & $2.70 \mathrm{de}$ \\
CPMMV sap & 0.75 & $1.96 \mathrm{c}$ & $2.75 \mathrm{~cd}$ & $2.80 \mathrm{de}$ & $2.95 \mathrm{cde}$ & $2.95 \mathrm{cde}$ \\
& 1.5 & $1.50 \mathrm{~cd}$ & $2.30 \mathrm{~cd}$ & $2.57 \mathrm{de}$ & $2.57 \mathrm{de}$ & $2.57 \mathrm{de}$ \\
Negative control & 3.0 & $0.83 \mathrm{~d}$ & $1.92 \mathrm{de}$ & $1.92 \mathrm{de}$ & $1.92 \mathrm{ef}$ & $1.92 \mathrm{ef}$ \\
Positive control & 6.0 & $0.00 \mathrm{e}$ & $0.61 \mathrm{e}$ & $0.61 \mathrm{e}$ & $0.61 \mathrm{~g}$ & $0.61 \mathrm{~g}$ \\
\hline CV (\%) & - & $0.12 \mathrm{~d}$ & $0.23 \mathrm{e}$ & $0.23 \mathrm{e}$ & $0.34 \mathrm{~g}$ & $0.34 \mathrm{~g}$ \\
& - & $10.90 \mathrm{a}$ & $22.35 \mathrm{a}$ & $25.11 \mathrm{a}$ & $31.24 \mathrm{a}$ & $31.27 \mathrm{a}$ \\
\hline
\end{tabular}

DAI: days after inoculation; CV: coefficient of variation; the same letter at each column showed the no significance different based on Duncan multiple range test at significance level of 5\%. 
Tabel 3. The potency of cashew nutshell extract as plant resistance inducer towards CPMMV infection in soybean

\begin{tabular}{lcccc}
\hline \multirow{2}{*}{ Extract treatment } & \multirow{2}{*}{$\begin{array}{c}\text { Extract } \\
\text { concentration (\%) }\end{array}$} & AUDPC (Days) & \multicolumn{2}{c}{ Inhibition (\%) } \\
\cline { 4 - 5 } & 0.75 & 87.42 & Local & Systemic \\
\hline Before CPMMV inoculation & 1.5 & 82.28 & 65.23 & 48.70 \\
& 3.0 & 50.44 & 83.60 & 46.25 \\
& 6.0 & 39.82 & 85.18 & 66.49 \\
After CPMMV inoculation & 0.75 & 115.78 & 30.32 & 18.18 \\
& 1.5 & 108.56 & 48.59 & 25.84 \\
& 3.0 & 95.49 & 63.71 & 40.20 \\
& 6.0 & 56.10 & 76.25 & 52.68 \\
Mixed with & 0.75 & 58.65 & 74.12 & 54.17 \\
CPMMV sap & 1.5 & 32.29 & 87.43 & 66.92 \\
& 3.0 & 10.07 & 92.36 & 70.34 \\
Negative control & 6.0 & 5.25 & 97.85 & 86.21 \\
Positive control & - & 2.43 & 99.26 & 99.53 \\
Average (\%) & - & 198.70 & 0.00 & 0.00 \\
\hline
\end{tabular}

with CPMMV sap showed healthy plants without mild yellow blotch on 8 test plants until the end of observation for each treatment and had absorbance values $<2$ times NAE of negative controls and were detected negative with CPMMV antiserum, except CNS extract treatment (6.0\%) after CPMMV inoculation and mixing CNS extract $(0.75 \%)$ with CPMMV sap showing healthy plants and mild yellow blotch. This healthy-looking plant with mild yellow blotch had an absorbance value $>2$ times NAE from negative control and positive detection. Whereas twelve out of five treatments above showed clear yellow and slightly mottled symptoms and were detected positive with CPMMV antiserum. However, the treatment of cashew nutshell extract at a concentration of $6.0 \%$ before and after the inoculation of CPMMV caused symptoms of phytotoxicity (Table 4). Plants appear healthy without visible symptoms of mild yellow blotch and do not react with CPMMV antiserum allegedly due to the influence of bioactive compounds from the application of these extracts that could reach the active area of the ribosome, thus preventing the removal of the protein envelope from the virus. The bioactive compound in the CNS extract was anacardic acid with a concentration of $76.93 \%$, while the remaining $21.22 \%$ consisted of cardols $(12.75 \%)$, cardanol (4.66\%) and 2-methyl-cardols (3.81\%) (Andayanie et al., 2019). According to Cecílio et al. (2012) and Aderiye et al. (2015) anacardic acid from cashew nutshell extract has a close relationship with salicylic acid which is an inhibitor and antiviral against Rotaviruses that cause diarrhea. Mirabilis jalapa leaf extract was also able to increase salicylic acid content to activate the formation of PR protein and has a role for induced systemic resistance against Bean common mosaic virus (Kurniingsih \& Damayanti, 2012). Bioactive compounds from natural antivirals will have effectiveness if the inducer was applied shortly after challenge inoculation with the virus. Plants with low viral concentrations have high peroxidase activity, as reported in tobacco resistance response from TMV infection (Matthews, 1992; Madhusudhan et al., 2011).

\section{CONCLUSION}

This research succeeded in proving the effectiveness of cashew nutshell extract and its potential content as an antiviral that was able to suppress CPMMV infection in soybeans. From the tested treatments and concentrations, the mix of cashew nutshell extract at a concentration of $6.0 \%$ with sap CPMMV has the lowest AUDPC value with the highest percentage of local and systemic inhibition and the lowest CPMMV titer. Although the virus titer in the treatment did not have a significant difference with the virus titer of mix cashew nutshell extract at a concentration of $3.0 \%$ with CPMMV sap and the cashew nutshell extract 
Table 4. The ELISA absorbance value (EAV) of selected treatment from CNS extract as resistance inducer

\begin{tabular}{|c|c|c|c|c|}
\hline \multirow{2}{*}{ Extract treatment } & \multirow{2}{*}{$\begin{array}{c}\text { Extract } \\
\text { concentration } \\
(\%)\end{array}$} & \multirow{2}{*}{ Symptom } & \multicolumn{2}{|c|}{ ELISA result ${ }^{*}$} \\
\hline & & & EAV & Reaction \\
\hline \multirow[t]{4}{*}{ Before CPMMV inoculation } & 0.75 & $\begin{array}{l}\text { Clear yellow blotch on the } \\
\text { leaves, no wrinkle observed }\end{array}$ & $0.621 \mathrm{~b}^{* *}$ & + \\
\hline & 1.5 & $\begin{array}{l}\text { Clear yellow blotch on the } \\
\text { leaves, no wrinkle observed }\end{array}$ & $0.606 \mathrm{~b}$ & + \\
\hline & 3.0 & Healthy leaves & $0.490 \mathrm{c}$ & - \\
\hline & 6.0 & $\begin{array}{l}\text { Healthy leaves, mild } \\
\text { phytokinesis on the sprayed } \\
\text { area }\end{array}$ & $0.458 \mathrm{~cd}$ & - \\
\hline \multirow[t]{4}{*}{ After CPMMV inculation } & 0.75 & $\begin{array}{l}\text { Clear yellow blotch on the } \\
\text { leaves, no wrinkle observed }\end{array}$ & $0.634 \mathrm{~b}$ & + \\
\hline & 1.5 & $\begin{array}{l}\text { Clear yellow blotch on the } \\
\text { leaves, no wrinkle observed }\end{array}$ & $0.628 \mathrm{~b}$ & + \\
\hline & 3.0 & $\begin{array}{l}\text { Clear yellow blotch on the } \\
\text { leaves, no wrinkle observed }\end{array}$ & $0.622 b$ & + \\
\hline & 6.0 & $\begin{array}{l}\text { Leaves appear healthy, mild } \\
\text { yellow blotch observed, mild } \\
\text { phytokinesis on the sprayed } \\
\text { area }\end{array}$ & $0.619 \mathrm{~b}$ & + \\
\hline \multirow[t]{4}{*}{$\begin{array}{l}\text { Mixed with } \\
\text { CPMMV sap }\end{array}$} & 0.75 & $\begin{array}{l}\text { Leaves appear healthy, mild } \\
\text { yellow blotch observed }\end{array}$ & $0.596 \mathrm{bc}$ & + \\
\hline & 1.5 & Healthy leaves & $0.513 \mathrm{c}$ & - \\
\hline & 3.0 & Healthy leaves & $0.451 \mathrm{~cd}$ & - \\
\hline & 6.0 & Healthy leaves & $0.440 \mathrm{~cd}$ & - \\
\hline Negative control & - & Healthy leaves & $0.296 \mathrm{~d}$ & - \\
\hline Positive control & - & $\begin{array}{l}\text { Severe mosaic symptom, leaf } \\
\text { distortion, plant dwarf }\end{array}$ & $1.045 \mathrm{a}$ & ++ \\
\hline
\end{tabular}

Coefficient of variation $(\%)$

21.758

${ }^{*}$ The EAV of negative control $=0.296$, EAV of positive control $=1.045$; The reaction was positive if the EAV of the sample in twice than EAV of negative control (positive e" 0,592); + (visually light yellow); ++ (visually dark yellow); " (visually clear);* The same letter at each column showed the no significance different based on Duncan multiple range test at significance level of 5\%.

at a concentration of $6.0 \%$ before inoculation of CPMMV. However, the treatment of cashew nutshell extract concentration of $6.0 \%$ prior to the inoculation of CPMMV caused phytotoxicity. Therefore for application in the field, it is necessary to use cashew nutshell extract at concentrations lower than $6.0 \%$ before CPMMV infection.

\section{ACKNOWLEDGMENT}

Acknowledgments are conveyed to the DRPM Ministry of Research, Technology and Higher Education of the Republic of Indonesia who have funded this research and publication through the Leading Higher
Education Basic Research scheme. The author would also like to acknowledge: 1) Head of the Virology Laboratory, Universitas Merdeka Madiun; 2) The Head of Bioscience Laboratory, Politeknik Negeri Jember; 3) The Head of Ngale Beans and Tuber Crops Research Installation in Ngawi who facilitated this research.

\section{REFERENCES}

Aderiye BI, David OM, \& Atere VA. 2015. Administration of cashew extracts in the treatment of some infections and diseases. $A d v$. Med. Plant Res. 3(3): 75-86. 
Andayanie WR, Sumardiyono YB, Hartono S, \& Yudono P. 2011. Incidence of soybean mosaic disease in East Java Province. Agrivita J. Agricultural Science. 33(1): 15-21.

Andayanie WR \& Adinurani PG. 2014. Seleksi galur dari populasi F4 kedelai yang tahan terhadap penyakit mosaik (Soybean mosaic virus) dan berdaya hasil tinggi. J. HPT Tropika. 14(2): 152159.

Andayanie WR, Santosa V, \& Rahayu M. 2017. Resistance to Soybean mosaic virus with high yield on F7 soybean lines. Int. J. Agric. Biol. 19(2): 226-232.

Andayanie WR, Ermawati N, \& Iswati R. 2018. Use tillage system and botanical herbicide of cashew nut shell extract on losses nutrient and organic matter in the sloping land. AIP Conf. Proc. 2024. 020018 (2018).

Andayanie WR \& Ermawati N. 2019. Developmental effect of cashew nut shell extract against nymphal instar of silver leaf whitefly (Bemisia tabaci Genn.). IOP C. Ser. Earth Env. Sci. 293012039.

Andayanie WR, Nuriana W, \& Ermawati N. 2019. Bioactive compounds and their their antifeedant activity of cashew nut (Anacardium occidentale L.) shell extract against Bemisia tabaci, (Gennadius, 1889) (Hemiptera: Aleyrodidae). Acta Agric. Slov. 113(2): 281-288.

Arif M \& Hassan S. 2002. Evaluation of resistance in soybean germplasm to Soybean mosaic potyvirus under field condition. Online J. Biol. Sci. 2(9): 601-604.

Cecílio AB, de Faria DB, Oliveira PdeC, Caldas S, de Oliveira DA, Sobral MEG, Duarte MGR, Moreira CPdeS, Silva CG, \& de Almeida VL. 2012. Screening of Brazilian medicinal plants for antiviral activity against rotavirus. $J$. Ethnopharmacol. 141(3): 975-981.

Elbeshehy EKF. 2017. Inhibitory activity of different medicinal plants extracts from Thuja orientalis, Nigella sativa L., Azadirachta indica and Bougainvillea spectabilis against Zucchini yellow mosaic virus (ZYMV) infecting Citrullus lanatus. Biotechnol. Biotechnol. Equip. 31(2): 270-279.
Garcia NZT, Barbosa GF, Matias R, Pedrinho DR, Bono JAM, \& Martini D. 2018. Antifungal potential of cashew nut shell liquid in the control of plant pathogens. Biosci. J. 34(1): 95-103.

Gunaeni N, Wulandari AW, \& Hudayya A. 2015. Pengaruh bahan ekstrak tanaman terhadap pathogenesis related protein dan asam salisilat dalam menginduksi resistensi tanaman cabai merah terhadap virus kuning keriting. J. Hort. 25(2): 160-170.

Kristyaningrum VT, Martosudiro M, \& Hadiastono T. 2015. Ekstrak bayam duri (Amaranthus spinosus L.) sebagai penginduksi ketahanan tanaman cabai besar (Capsicum annuum L.) terhadap infeksi Cucumber mosaic virus (CMV). JHPT. 3(1): 61-66.

Kurnianingsih L \& Damayanti TA. 2012. Lima ekstrak tumbuhan untuk menekan infeksi Bean common mosaic virus pada tanaman kacang panjang. $J$. Fitopatol. Indones. 8(6): 155-160.

Madhusudhan KN, Vinayarani G, Deepak SA, Niranjana SR, Prakash HS, Singh GP, Sinha AK, \& Prasad BC. 2011. Antiviral activity of plant extracts and other inducers against Tobamoviruses infection in bell pepper and tomato plants. Int. J. Plant Pathol. 2(1): 35-42.

Matthews REF. 1992. Fundamentals of Plant Virology. Academic Press, California.

Murphy AM, Gilliland A, Wong CE, West J, Singh DP, \& Carr JP. 2001. Signal transduction in resistance to plant viruses. Eur. J. Plant Pathol. 107(1): 121-128.

Petrov NM, Stoyanova M, \& Valkova M. 2016. Antiviral activity of plant extract from Tanacetum vulgare against Cucumber mosaic virus and Potato virus Y. J. BioSci. Biotechnol. 5(2): 189-194.

Saleh N. 2007. Sistem produksi kacang-kacangan untuk menghasilkan benih bebas virus. Iptek Tanaman Pangan. 2(1): 66-76.

Strange RN. 2003. Introduction to Plant Pathology. John Willey and Sons Ltd, New York.

Sudjaroen Y, Thongkao K, \& Suwannahong K. 2018. Antioxidant, antibacterial and cytotoxicity activities of cashew (Anacardium occidentale) nut shell waste. Int. J. Green Pharm. 12(1): S229-S234. 
Tavassoli M, Shahraeen N, \& Ghorbani S. 2008. Detection and some properties of Cowpea mild mottle virus isolated from soybean in Iran. PJBS. 11(23): 2624-2628.
Towaha J \& Ahmadi NR. 2011. Pemanfaatan cashew nut shell liquid sebagai sumber fenol alami pada industri. Buletin RISTRI. 2(2): 187-198. 